\title{
KARAKTERISTIK LACTATE THRESHOLD PADA ATLET TAEKWONDO DAERAH ISTIMEWA YOGYAKARTA SELAMA KOMPETISI
}

\author{
Widiyanto, Awan Hariono, Devi Tirtawirya \\ FIK Universitas Negeri Yogyakarta \\ Email: Widiyanto_uny@yahoo.com
}

\begin{abstract}
Abstrak: Karakteristik Lactate Threshold pada Atlet Taekwondo Daerah Istimewa Yogyakarta selama Kompetisi. Penelitian ini bertujuan untuk mengetahui karakteristik lactate threshold pada atlet Taekwondo Daerah Istimewa Yogyakarta selama kompetisi. Penelitian ini merupakan penelitian diskriptif yang dilakukan dengan teknik survei. Teknik pengumpulan data dilakukan dengan tes yang bertujuan untuk mengetahui seberapa tinggi kadar asam laktat darah pada atlet Taekwondo Daerah Istimewa Yogyakarta selama kompetisi. Sampel yang digunakan dalam penelitian ini adalah atlet Taekwondo DIY yang ikut dalam kejuaraan Taekwondo (invitasi Taekwondo antar perguruan tinggi, Porprov DIY, dan POMNAS). Penelitian ini dilaksanakan pada bulan September 2013 di Gedung Olahraga Universitas Pembangunan Nasional Daerah Istimewa Yogyakarta. Dalam penelitian ini dilakukan analisa statistik dengan paired sample t-test. Semua analisa statistik dikerjakan dengan aplikasi komputer menggunakan seri program SPSS for windows versi 19 dengan taraf signifikansi 5\%. Hasil uji beda kadar asam laktat pada pengukuran ke-1, ke-2, ke-3, ke-4, dan ke-5 menunjukkan bahwa terjadi kenaikan kadar asam laktat darah. Sedangkan hasil uji beda kadar asam laktat darah pada pengukuran ke 6 terjadi penurunan. Kadar asam laktat tertinggi dihasilkan pada pengukuran ke-5 atau pada Ronde ke-3. Pemulihan dengan waktu 10 menit setelah pertandingan belum cukup memulihkan kadar asam laktat darah pada kondisi sebelum bertanding atau saat istirahat.
\end{abstract}

Kata Kunci: Taekwondo, asam laktat darah

Abstract: Characteristics of Lactate Threshold in Yogyakarta Special Region Taekwondo Athletes during Competition. This study aimed at investigating the characteristics of lactate threshold in Taekwondo Yogyakarta Special Region athletes during competition. This research is a descriptive study conducted with survey techniques. Data was collected with a test that aims to understand how high levels of lactic acid in the blood of Yogyakarta Taekwondo athletes during competition. The sample used in this study is a DIY Taekwondo athletes who participate in Taekwondo championship. This study was conducted in September 2013 at Sports Hall the National Development University of Yogyakarta. In this research, statistical analysis by paired sample t-test. All statistical analyzes were performed with computer applications using serial program SPSS for Windows version 19, with a significance level of $5 \%$. Different test results on the measurement of lactic acid levels at 1 , at 2 , at 3 , at 4 , and 5 to show that an increase in blood lactic acid levels. While the results of different tests on the blood lactic acid levels at 6 measurements decrease. Highest levels of lactic acid produced in the measurement to 5 or in Round 3. Recovery with a time of 10 minutes after the match has not been enough to restore blood lactic acid levels in condition before the match or at rest.

Key Word: Taekwondo, blood lactate levels 


\section{PENDAHULUAN}

Prestasi Taekwondo dalam kurun waktu beberapa tahun ini mengalami pasang surutyang kurang menyenangkan. Keadaan tersebut disebabkan oleh beberapa faktor di antaranya: faktor sosial, ekonomi, dan politik yang relatif belum stabil. Sebagai akibatnya pola pembinaan prestasi Taekwondo di Indonesia belum dapat dilakukan secara merata dan berkesinambungan. Oleh karena sistem pelatihan yang dilakukan secara kontinyu, bertahap, dan berkelanjutan tidak dapat diterapkan secara proporsional. Artinya kolaborasi antara praktisi dan akademisi belum terjalin secara harmonis. Untuk itu diperlukan perhatian secara khusus terhadap sistem pembinaan prestasi olahraga Taekwondo di Indeonesia.

Kesuksesan atlet dalam berprestasi tidak hanya ditunjang oleh keterampilan dan teknik yang memadai namun juga perlu ditunjang oleh profil fisiologis yang baik, dalam hal ini merupakan kombinasi dari kekuatan (strength), kelenturan (flexibility), kelincahan (agility), kecepatan (speed), kapasitas aerobik, dan kapasitas anaerobik (Noakes. 2000). Kapasitas aerobik secara sederhana digambarkan sebagai kapasitas tubuh dalam melakukan aktivitas fisik tanpa membuat seseorang kehabisan napas (running out of breath), sedangkan kapasitas anaerobik merupakan kapasitas atau lama seseorang agar mampu melakukan kerja intensitas tinggi ketika seseorang seakan kehabisan napas (Tessitore \& Meeusen, 2005). Kerja anaerobik ditentukan oleh level substrat pembentuk energi dan kapasitas clearance (pembersihan) laktat. Level substrat yang tinggi serta clearance laktat yang cepat dapat meningkatkan baik kapasitas maupun stabilitas kerja anaerobik (Monedero \& Donne, 2000).
Produksi asam laktat sangat tergantung pada intesitas aktivitas fisik. Sewaktu melakukan aktivitas aerobik dan anaerobik dengan durasi dan intensitas yang relatif tinggi dapat menyebabkan kelelahan. Hal ini disebabkan karena terjadi peningkatan asam laktat di dalam otot sehingga $\mathrm{pH}$ yang rendah akan mengganggu pembentukan energi yang diperlukan selama kontraksi otot. Selain itu kelelahan tersebut dapat pula disebabkan karena kehabisan cadangan energi ATP dan fosfokreatin otot serta dapat pula disebabkan oleh hal-hal lain.

Akhir-akhir ini penentuan ambang anaerobik di bidang olahraga dikembangkan menjadi dasar untuk menentukan dosis dan bentuk latihan yang berhubungan dengan energi predominan pada salah satu cabang olah raga tertentu. Pemeriksaan kadar laktat darah pada atlet penting untuk menentukan batas ambang laktat (lactate threshold). Akumulasi laktat di dalam darah menentukan keseimbangan antara jumlah laktat yang diproduksi dan jumlah laktat yang dibersihkan (lactate clearance).

\section{METODE}

Penelitian ini bertujuan untuk mengetahui karakteristik lactate threshold pada atlet Taekwondo Daerah Istimewa Yogyakarta selama kompetisi. Penelitian ini merupakan penelitian diskriptif yang dilakukan dengan teknik survei. Teknik pengumpulan data dilakukan dengan tes yang bertujuan untuk mengetahui seberapa tinggi kadar asam laktat darah pada atlet Taekwondo Daerah Istimewa Yogyakarta selama kompetisi.

Penggukuran kadar asam laktat darah dilakukan sebanyak enam kali. Penggukuran kadar asam laktat darak 
yang ke-1 dilakukan pada saat atlet dalam kondisi istirahat, penggukuran kadar asam laktat darah yang ke-2 dilakukan saat atlet selesai melakukan pemanasan, penggukuran kadar asam laktat darah yang ke-3 dilakukan pada saat istirahat ronde ke-1, penggukuran kadar asam laktat darah yang ke-4 dilakukan pada saat istirahat ronde ke-2, penggukuran kadar asam laktat darah yang ke-5 dilakukan pada saat istirahat ronde ke3 , dan penggukuran kadar asam laktat darah yang ke-6 dilakukan 20 menit setelah istirahat ronde ke-3 (selesainya pertandingan). Dalam penelitian ini dilakukan analisa statistik dengan paired sample t-test. Semua analisa statistik dikerjakan dengan aplikasi komputer menggunakan seri program SPSS for windows versi 19 dengan taraf signifikansi 5\%.

\section{HASIL DAN PEMBAHASAN \\ Hasil Analisa Diskriptif}

Hasil analisa diskriptif yang berupa jumlah sampel $(\mathrm{N})$, rata-rata (mean), dan standar deviasi (SD) variabel asam laktat darah pada tiap-tiap pengukuran ditampilkan pada Tabel 1.

Tabel 1. Hasil Analisa Diskriptif Variabel Asam Laktat Darah

\begin{tabular}{lccc}
\hline \multicolumn{1}{c}{ Variabel } & & & \\
Kadar Laktat & N & Mean & SD \\
\hline Laktat Istirahat & 7 & 1,71 & 0,38 \\
Laktat Pemanasan & 7 & 4,88 & 0,38 \\
Laktat ronde 1 & 7 & 8,78 & 0,429 \\
Laktat ronde 2 & 7 & 12,17 & 1,28 \\
Laktat ronde 3 & 7 & 12,47 & 1,28 \\
Laktat Istirahat & 7 & 4,08 & 0,70 \\
20' & & & \\
\hline
\end{tabular}

\section{Hasil Analisa Uji Beda Kadar Asam Laktat Darah}

Pengukuran kadar asam laktat darah dilakukan secara berulang-ulang (time series). Pengukuran kadar asam laktat darah dilakukan sebanyak 6 kali setiap atlet. Pengukuran ke-1 pada saat istirahat atau sebelum melakukan pemanasan, pengukuran ke-2 dilakukan setelah pemanasan, pengukuran ke-3 dilakukan saat pertandingan yaitu pada ronde ke-1, pengukuran ke-4 dilakukan saat pertandingan ronde ke-2, pengukuran ke-5 dilakukan pada saat ronde ke-3, pengukuran ke-6 dilakukan 20 menit setelah pertandingan ronde ke-3 berakhir. Untuk mengetahui perbedaan dari setiap pengukuran dilakukan uji beda dengan uji paired sample t-test. Hasil analisa uji paired sample t-test terhadap variabel asam laktat darah pada tiap-tiap pengukuran dapat dilihat pada Tabel 2.

Tabel 2. Hasil Analisa Hasil Uji Beda Kadar Asam Laktat Darah

\begin{tabular}{cccc}
\hline $\begin{array}{c}\text { Varia- } \\
\text { bel }\end{array}$ & \multicolumn{3}{c}{ Paired Sample t-test } \\
\cline { 2 - 4 } & Pengukuran & Pengukuran & Sig. \\
\hline & 1 & 2 & 0,00 \\
& & 3 & 0,00 \\
& & 4 & 0,00 \\
& & 5 & 0,00 \\
& 2 & 3 & 0,00 \\
Kadar & & 4 & 0,00 \\
Asam & & 5 & 0,00 \\
Laktat & & 6 & 0,00 \\
Darah & 3 & 4 & 0,03 \\
& & 5 & 0,00 \\
& & 6 & 0,00 \\
& & 5 & 0,665 \\
& 4 & 6 & 0,00 \\
& & 6 & 0,00 \\
\hline
\end{tabular}




\section{Pembahasan}

Kadar Asam Laktat Darah saat Istirahat

Penelitian yang telah dilakukan menunjukkan bahwa kadar asam laktat darah saat istirahat pada orang coba berkisar antara 1,2 - 2,3 $\mathrm{mMol} / \mathrm{l}$ dengan jenis kelamin laki-laki. Kadar asam laktat darah dapat dipergunakan sebagai parameter untuk mengetahui respon aktivitas fisik. Besarnya kadar asam laktat darah dinyatakan dalam satuan mMol/l (Guyton \& Hall, 2006). Besarnya nilai kadar asam laktat darah pada orang sehat dalam keadaan istirahat (sebelum melakukan aktivitas fisik) berkisar 1-2 mMol/l (Janssen, 1989). Oleh karena itu, dalam penelitian ini pengukuran kadar asam laktat istirahat dilakukan sebelum orang coba melakukan aktivitas fisik.

\section{Kadar Asam Laktat Darah setelah Pemanasan}

Dari hasil penelitian yang telah dilakukan diperoleh hasil bahwa ratarata kadar asam laktat darah setelah melakukan pemanasan adalah sebesar 4,3-5,4 mMol/l. Penelitian yang telah dilakukan oleh McGuiggin (1993), menunjukkan hasil bahwa kadar asam laktat kelompok tidak terlatih adalah sekitar 7,6-8,8 mMol/l. Hasil penelitian yang telah dilakukan menunjukkan bahwa orang coba termasuk kelompok terlatih, karena kadar asam laktat darah tersebut belum mencapai nilai maksimal. Kadar asam laktat darah maksimal pada orang dapat mencapai $20 \mathrm{mMol} / \mathrm{l}$.

Latihan fisik yang dilakukan dengan intensitas mendekati maksimal (sub maksimal) atau latihan maksimal akan meningkatkan kadar asam laktat darah (Jansen, 1989). Pada latihan fisik yang dilakukan dengan intensitas latihan yang semakin meningkat juga dapat meningkatkan kadar asam laktat darah
(Meicer, 1991). Latihan fisik yang dilakukan dengan intensitas latihan yang semakin meningkat akan menyebabkan terjadinya pergeseran sistem energi, yaitu dari pasokan sistem energi aerobik ke sistem energi anaerobik, kondisi ini akan dapat menyebabkan terjadinya peningkatan kadar asam laktat darah.

Adanya perbedaan kadar asam laktat darah setelah melakukan pemanasan merupakan akibat dari perlakuan yang diberikan pada orang coba. Berdasar nilai rata-rata kadar asam laktat darah awal dan kadar asam laktat darah setelah pemanasan terlihat adanya peningkatan kadar asam laktat darah dari sebelum melakukan aktivitas fisik dan setelah melakukan aktivitas fisik. Hal ini menunjukkan bahwa aktivitas fisik yang dilakukan memiliki respons terhadap peningkatan metabolisme untuk memenuhi kebutuhan energi yang dibutuhkan.

Pada aktivitas fisik yang semakin tinggi akan menyebabkan terjadinya pergeseran pasokan energi dari sistem energi aerobik bergeser ke sistem energi anaerobik. Menurut Merceir (1991), aktivitas fisik yang dilakukan dengan intensitas yang semakin tinggi akan meningkatkan kadar asam laktat darah. Dengan meningkatnya aktivitas fisik, maka kebutuhan energi dan kebutuhan akan oksigen juga akan meningkat pula. Pasokan kebutuhan oksigen dapat ditingkatkan dengan meningkatnya respirasi paru dan denyut jantung. Ketika melakukan akivitas fisik yang maksimal peningkatan respirasi dan denyut jantung tidak dapat dicukupi, sehingga terjadi metabolisme anaerobik untuk pemenuhan kebutuhan energinya dan kondisi ini dapat meningkatkan kadar asam laktat baik asam laktat dalam darah maupun di dalam otot. 


\section{Kadar Asam Laktat Saat Bertanding}

Dari hasil penelitian yang telah dilakukan diperoleh hasil bahwa ratarata kadar asam laktat darah saat pertandingan pada Ronde I adalah sebesar 8,2-9,3 mMol/l, rata-rata kadar asam laktat darah saat pertandingan pada Ronde II adalah sebesar 10,7 - 14,2 $\mathrm{mMol} / \mathrm{l}$, dan rata-rata kadar asam laktat darah saat pertandingan pada Ronde III adalah sebesar 10,7-14,5 mMol/l. Dilihat dari nilai rata-rata kadar asam laktat darah saat pertandingan pada Ronde I, Ronde II, dan Ronde III selalu mengalami kenaikan. Hasil penelitian yang telah dilakukan menunjukkan bahwa orang coba termasuk kelompok terlatih, karena kadar asam laktat darah tersebut belum mencapai nilai maksimal. Kadar asam laktat darah maksimal pada orang dapat mencapai $20 \mathrm{mMol} / \mathrm{l}$.

Hasil analisis data dengan paired sample t-tes pada pengukuran kadar asam laktat darah pada Ronde 1, Ronde 2, dan Ronde 3 pada tabel 2 di atas diketahui nilai $\mathrm{P}=0,00$ untuk analisis uji beda pada Ronde 1 dengan Ronde 2, dan Ronde 3, karena $\mathrm{P}<0,05$ maka terdapat perbedaan bermakna kadar asam laktat darah pada Ronde 1 dengan Ronde 2 dan Ronde 3. Hasil analisis data dengan uji paired sample t-tes pada pengukuran kadar asam laktat darah pada Ronde 2, dengan Ronde 3 pada Tabel 2 di atas diketahui nilai $\mathrm{P}=0,665$, karena $\mathrm{P}>0,05$ maka tidak terdapat perbedaan bermakna kadar asam laktat darah pada Ronde 2 dan Ronde 3.

Pertandingan dalam Taekwondo kyorugi dilakukan dalam tiga ronde, dengan waktu istirahat antar ronde 1 menit. Tiap ronde dalam pertandingan Taekwondo memerlukan waktu 2 menit bersih. Artinya, ketika wasit menghentikan pertandingan karena terjadi insiden, maka waktu tersebut tidak termasuk waktu bertanding. Dengan demikian waktu pertandingan adalah total waktu efektifyang di gunakan selama pertandingan berlangsung, yaitu diawali dari aba-aba "mulai (shijak) "sampai dengan aba-aba" berhenti (geuman)".

Selama berlangsungnya pertandingan, akumulasi waktu yang digunakan dapat dihitung sebagai berikut: (1) waktu yang digunakan dalam tiga babak adalah 480 detik, (2) dalam melakukan serang bela (fight) untuk tiap babak diperlukan waktu rata-rata 126 detik, (3) recovery dalam tiap babak kira-kira 234 detik, (4) interval antar babak dengan waktu 120 detik. Dengan demikian persentase dari waktu yang digunakan selama dalam pertandingan adalah 26,25\% untuk fight (waktu kerja), 48,75\% untuk recovery antarfight, dan 25\% untuk interval antarbabak. Untuk itu, total waktu istirahat baik aktif maupun pasif sebanyak 73,75\%, sedangkan total waktu efektif yang digunakan untuk fight selama dalam pertandingan sebanyak $26,25 \%$.

Berdasarkan total persentase waktu yang digunakan selama dalam pertandingan, energi yang dominan digunakan dalam Taekwondo adalah $73,75 \%$ aerobik dan $26,25 \%$ adalah anaerobik. Bila dilihat dari energi yang digunakan pada saat melakukan fight (waktu kerja), maka energi yang dominan digunakan adalah sistem anaerobik. Untuk itu dalam Taekwondo kategori tanding memerlukan $73,75 \%$ sistem energi ATP-PC, 16,25\% sistem energi LA$\mathrm{O}_{2}$, dan $10 \%$ dari oksigen $\left(\mathrm{O}_{2}\right)$.

Dalam penelitian yang dilakukan oleh Von Duvillard (1994) dan Williams (1993) membuktikan bahwa kadar asam laktat darah mempunyai hubungan yang signifikan dengan menambahkan beban latihan dan lamanya latihan itu dilakukan. Hal ini disebabkan oleh adanya 
keterlibatan metabolisme anaerobik atau sistem asam laktat. Williams (1993), mengatakan bahwa pembentukan asam laktat akan terjadi pada kerja progresif yang dinamis dari intensitas kerja maksimal. Kondisi yang demikian akan lebih mempercepat terjadinya penumpukan asam laktat baik dalam darah maupun di dalam otot.

Brooks (1992) berkaitan dengan masalah laktat berpendapat bahwa aktivitas fisik menggunakan sistem aerobik, tidak akan terjadi penumpukan laktat yang berlebihan, karena produksi laktat dengan oksidasi laktat berjalan secara seimbang. Di samping otot menghasilkan laktat, otot juga mengonsumsi (menggunakan) laktat sebagai sumber energi melalui proses oksidasi aerobik, tatapi pada saat aktivitas fisik meningkat sampai pada ambang anaerobik terjadi ketidak seimbangan antara laktat yang dihasilkan dan laktat yang digunakan. Dijelaskan pula bahwa pada saat latihan di atas ambang anaerobik (maksimal sampai supramaksimal) mekanisme "ulangalik laktat" (lactate shuttle) artinya laktat yang dihasilkan oleh salah satu otot akan dilepas dan ditangkap oleh otot yang lainnya tidak berjalan secara normal (terganggu), sehingga terjadi penumpukan laktat di otot. Lactate shuttle akan kembali normal pada pemulihan atau penurunan intensitas aktivitas fisik (Brooks, 1992).

Kadar asam laktat yang tinggi akan sangat merugikan kinerja fisik seseorang, karena penimbunan asam laktat dapat menyebakan terjadinya kelelahan dan menurunnya kekuatan otot, di samping itu tingginya konsentrasi kadar asam laktat juga dapat menurunkan kekuatan kontraksi otot, hal ini disebabkan oleh karena menurunnya daya ikat ion $\mathrm{Ca}^{2+}$ pada troponin dan meningkatnya daya ikat retikulum sarkoplasmik terhadap ion $\mathrm{Ca}^{2+}$. Kedua mekanisme ini akan menurunkan jumlah ion kalsium yang diikat pada troponin selama proses kontraksi otot sehingga akan sangat merugikan aktivitas fisik yang memerlukan kinerja tinggi.

Kadar asam laktat yang tinggi juga akan berpengaruh terhadap produksi ATP, sebab beberapa enzim yang berperan terhadap proses pembentukan ATP melalui glikolisis akan terhambat oleh keasaman dan akumulasi asam laktat kemungkinan akan menyebabkan terbatasnyakapasitasanaerobik. Menurut Janssen (1987), menyatakan bahwa kandungan laktat darah sebesar $6 \mathrm{mMol} / \mathrm{l}$ sudah dapat merugikan kinerja fisik, mengganggu tingkat koordinasi gerakan tubuh, menyebabkan terjadinya cedera olahraga dan terhambatnya kerja enzim glikolisis. Latihan fisik akan memberikan adaptasi dan toleransi terhadap kadar asam laktat dan pada orang terlatih dapat meningkatkan kapasitas transport laktat di otot skelet. Mcdermott (1993), menyatakan bahwa latihan selama enam minggu dengan menggunakan treadmill yang ditingkatkan secara progresif dapat meningkatkan transport asam laktat di dalam otot. Hassmen (1998) mengatakan bahwa waktu latihan dan waktu pemulihan sangatlah penting untuk diperhatikan, hal ini untuk menghindari adanya dampak negatif dalam latihan yang berlebihan (over training). Apabila dalam suatu latihan sampai terjadi over training, maka untuk pemulihannya diperlukan waktu yang relatif lebih lama, yang diperkirakan sampai 75 jam.

\section{Kadar Asam Laktat Darah Setelah Bertanding}

Dari hasil penelitian yang telah dilakukan diperoleh hasil bahwa ratarata kadar asam laktat darah setelah 
melakukan pemanasan adalah sebesar 3,4-5,3 mMol/l. Jika dibandingkan dengan nilai rata-rata kadar asam laktat ketika bertanding yang berkisar antara 8,2-14,5 mMol/l, kadar asam laktat darah setelah bertanding mengalami penurunan. Sport Resource Group Inc (1998) dalam (Freund, 1999) menyatakan bahwa kadar laktat darah setelah latihan maupun pertandingan dipengaruhi oleh kemampuan subyek, perbedaan distribusi, adaptasi tipe otot, tehnik atau efisiensi gerakan serta jenis tes yang digunakan. Penurunan kadar asam laktat melalui pemulihan setelah aktivitas fisik sangat bergantung pada intensitas latihan. Peningkatan kadar asam laktat darah memerlukan waktu yang sangat cepat, namun penurunannya memerlukan waktu yang lebih panjang karena laju penurunan laktat sangat rendah (Freund, 1999).

Dalam penelitian ini, waktu pengambilan kadar asam laktat darah setelah bertanding yaitu 20 menit. Waktu pemulihan 20 menit merupakan waktu yang relatif pendek dalam proses pemulihan dari aktivitas fisik submaksimal. Waktu 20 menit dalam pemulihan merupakan awal terjadinya oksidasi laktat dan yang lain digunakan membentuk glikogen kembali (Bangsbo, Juel, Hellsten, 1991). Menurut Fox (1993), pemulihan kadar laktat darah sampai pada tingkat normal (seperti keadaan sebelum latihan) memerlukan waktu antara 25-60 menit.

Oksidasi laktat secara aerobik merupakan bagian terbesar dalam proses pembersihan laktat. Adanya perbedaan dalam penurunan laktat pada saat pemulihan disebabkan oleh adanya perbedaan kecepatan oksidasi, yang dipengaruhi oleh bentuk dan beban pemulihan.
Freund (1999) menyatakan bahwa lama latihan dan lama pemulihan mempunyai hubungan eksponsial dengan kadar laktat darah. Pada saat latihan mencapai submaksimal sampai maksimal, kadar asam laktat meningkat tajam, namun pemulihannya memerlukan waktu yang lebih lama. Penelitian Evans (1993) membuktikan bahwa konsentrasi kadar asam laktat darah memiliki korelasi dengan waktu pengambilan. Hal ini membuktikan dengan pengambilan darah yang dilakukan dua menit dan lima menit setelah aktivitas fisik maksimal menunjukkan adanya peningkatan kadar asam laktat darah.

Reaksi puncak laktat setelah aktivitas fisik diperkirakan terjadi antara tiga sampai lima menit, namun ada perbedaan antara aktivitas fisik yang bersifat ketahanan dengan yang bersifat kecepatan. Pada aktivitas fisik yang bersifat ketahanan seperti pelari jarak jauh, perenang jarak jauh, balap sepeda, kadar asam laktat darah lebih cepat menurun setelah pemulihan (Sport Resource Group, 1998) dalam Freund (1999). Freund (1999) juga menyatakan bahwa reaksi puncak laktat setelah aktivitas fisik adalah lima menit. Gambaran kondisi kadar asam laktat darah setiap pengukuran dapat dilihat pada Gambar 1.

Pemulihan kadar asam laktat darah juga berhubungan dengan intensitas aktivitas fisik yang dilakukan. Hal ini berkaitan dengan transport laktat dari otot aktif ke otot yang kurang aktif. Pada aktivitas fisik sub maksimal, laktat dari otot akan dibawa ke darah ke otot lagi berjalan dengan baik. Tetapi aktivitas fisik maksimal transport laktat tidak lagi terjadi dengan mudah (mengalami hambatan) karena keterlibatan hampir semua otot dalam aktivitas fisik maksimal 


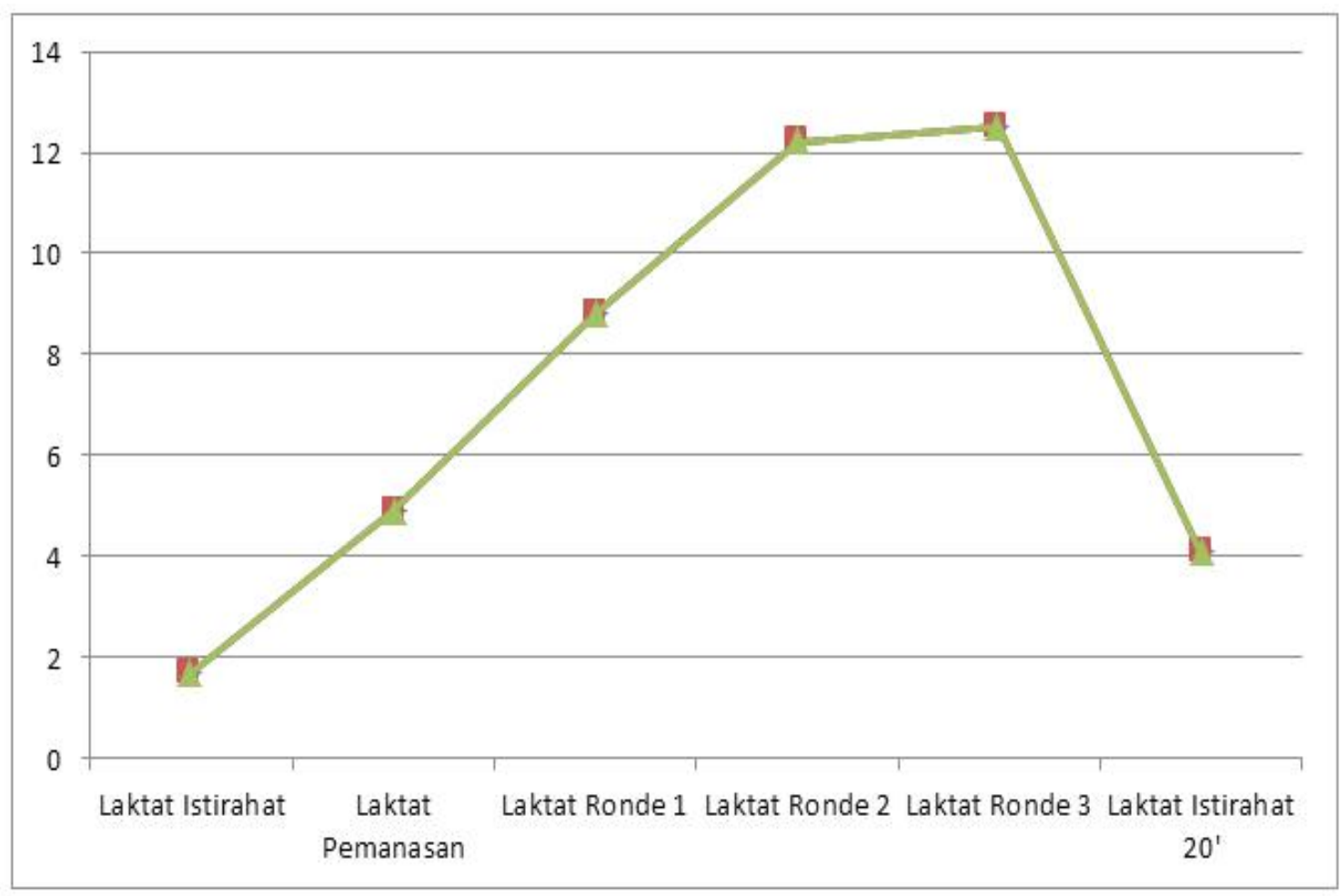

Gambar 1. Kondisi kadar asam laktat setiap pengukuran

Freund (1999). Sedangkan otot yang tidak terlibat dalam aktivitas berperan penting dalam transport laktat selama latihan. Oleh sebab itu transport laktat terjadi segera setelah latihan dihentikan atau intensitas aktivitas fisik diturunkan.

Pada waktu dilakukan pemulihan, otot akan mengeluarkan laktat ke sirkulasi darah untuk dibawa ke jaringan atau ke otot yang kurang aktif. Sebagian laktat otot dibersihkan melalui sirkulasi, sedangkan yang lain dikonversi kembali menjadi piruvat dengan bantuan enzim piruvat dehidrogenase. Sebagian piruvat akan dioksidasi menjadi karbondioksida dan air, sedang yang lain dirubah menjadi alanin (Lindinger, 1995). Laktat akan diproduksi oleh beberapa otot dan akan dioksidasi oleh otot yang lain menjadi piruvat untuk membentuk glikogen kembali, dengan demikian laktat akan berdifusi dari konsentrasi tinggi ke konsentrasi rendah.
SIMPULAN

Hasil uji beda kadar asam laktat pada pengukuran ke 1 , ke 2 , ke 3 , ke 4 , dan ke 5 menunjukkan bahwa terjadi kenaikan kadar asam laktat darah. Sedangkan hasil uji beda kadar asam laktat darah pada pengukuran ke 6 terjadi penurunan. Kadar asam laktat darah tertinggi dihasilkan pada pengukuran ke 5 atau pada Ronde ke 3, hal ini dikarenakan faktor akumulasi kadar asam laktat darah dari aktivitas sebelumnya. Pemulihan dengan waktu 20 menit setelah pertandingan belum cukup memulihkan kadar asam laktat darah pada kondisi sebelum bertanding atau saat istirahat.

\section{DAFTAR PUSTAKA}

Bangsbo, J., Juel, C., Hellsten, Y., and Saltin, B. 1997. Dissociattion between Lactate and Proton Exchange in Muscle during Intense Exercise in 
Man. Journals of Physiology. 504(2), 489-499.

Brooks, G.A., \& Gaeser, G.A. 1992. End points exercise physiology human bioenergetic and its application. Medicine Science Sport Exercise.

Evans, D.L, Haris, R.C, Snow, D.H. 1993. Correlation of racing performance with blood lactate and heart rate after exercise in thoroughbred horses. Equine vet J, 25(5): 441-445.

Fox, E.L., Bowers, R.W. \& Fross, M.L. 1993. The physiological basis of exercise and sport. USA: Wim. Brown Publisher.

Freund, H., Ayono-Enguelle S., Heitz, A., Ott, C., et all. 1999. Comparative lactate kinetics after short and prolonged submaximal exercise. Int J Sports Med, 11(4): 284-288.

Guyton, A.C. \& Hall. 2006. Text book of medical physiology. Printed in China. W.B. Saunders Company.

Hassmen. 1998. Glycogen and lactate metabolism during low intensity exercise in man. Acta Physiol Scand, 139(3): 475-484.

Janssen, P. 1989. Training Lactate Pulse Rate. Oule Finland: Polar Electro.

Lindiger, M.I., Mcksevi, R.S., Heigenhauser G.J. 1995. K+ and Lac- distribution in human during and after high intensity exercise: role in muscle fatigue attenuation. J Appl Physiol, 78(3): 765-777.

McDermott JC. Bonen A. 1993. Endurance training increases skeletal muscle lactate transport. Acta Physiol Scand. 147(3): 323-327.
McGuiggin. 1993. Effect of massage on blood flow and muscle fatique following isometric lumbar exercise. Journals Med Sci Monit. Japan: Department of Acupuncture, Tsukuba College of Technology. CR 173-8.

Meceir, J., Mercier, B., Preafaut, C. 1991. Blood lactate during the force velocity exercise test. Int J Sport Med. 12(1): 17-20.

Monedero, J. \& Donne, B. 2000. "Effect of recovery interventions on lactate removal and subsequent performance." International journal of sports medicine, 21(8): 593-597.

Noakes, T.D., 2000. Physiological models to understand exercise fatigue and the adaptations that predict or enhance athletic performance. Scandinavian Journal of Medicine \& Science in Sports. 10(3): 123-145.

Tessitore A, \&. Meeusen., 2005. "Aerobic and anaerobic profiles, heart rate and match analysis in older soccer players." Ergonomics 48(11): 13651377.

Von Duvillard S.P., Hagan, R.D. 1994. Independence of ventilation and blood lactate responses during grades exercise. Eur J Appl Physiol. 77(5): 434-438.

Williams \& Von Duvillard, S.P. 1993. Reability of peak lactate, heart rate and plasma volume following the wingate test. Med Sci Sport exercise. 30(9): 1456-1460.Um fugit reperci autessi bea simpore modistiur? 